\title{
O ROLI KAMERY W FILMACH WOJCIECHA SMARZOWSKIEGO ${ }^{1}$
}

KATARZYNA TARAS

\author{
Wydział Nauk Humanistycznych Uniwersytetu Kardynała Stefana \\ Wyszyńskiego w Warszawie \\ Faculty of Humanities Cardinal Stefan Wyszyński University in \\ Warsaw (Poland) \\ kasiataras@gmail.com
}

Najważniejszą inspiracją dla niniejszego szkicu była chęć powrotu do zagadnienia, którym zajmowałam się w 2003 roku, czego efektem był artykuł Komu cyfra sprzyja? ${ }^{1}$. Napisałam wtedy, że kamery cyfrowe, po pierwsze, skróciły czas czekania na możliwość zrealizowania filmu debiutanckiego, po drugie, stały się znaczącymi rekwizytami², umożliwiającymi bohaterom porozumienie - tak miało być na przykład w Moich pieczonych kurczakach (2002) Iwony Siekierzyńskiej, gdzie rozmowę skonfliktowanych małżonków zastąpiła projekcja nagranych przez żonę materiałów. Piszę „miało być”, ponieważ wątek „kamery cyfrowej grającej w filmie” poprowadzono tu zbyt ostentacyjnie, w sposób sprawiający wrażenie wymuszonego: umieszczono bohaterkę w szkole filmowej, przez co realizowanie przez nią materiałów nie wyrastało $z$ chęci odbudowania relacji małżeńskiej, tylko było przygotowywaniem szkolnego ćwiczenia. O wiele bardziej sprawnie i przekonująco kamerę cyfrową „obsadzono” ${ }^{3}$ w debiucie Łukasza Barczyka Patrzę na ciebie, Marysiu (2000), gdzie jest ona medium, dzięki któremu bohater dociera do swojej dziewczyny, poznaje osobę, z którą był związany i mieszkał kilka

1 K. Taras, Komu cyfra sprzyja, „Kwartalnik Filmowy” 2003, nr 43, s. 196-202.

2 Oczywiście, powstały też filmy, w których pojawiająca się na ekranie kamera cyfrowa była tylko rekwizytem informującym o statusie społecznym, zamożności bohaterów, a zatem i o tym, że kamera stała się jednym z przedmiotów powszechnie używanych przez Polaków.

3 Piszę „obsadzono", ponieważ w niniejszym szkicu zajmę się kamerą, która „występuje” w filmie, a nie tą, którą film realizowano. 
lat, a tak naprawdę niewiele o niej wiedział ${ }^{4}$. Michał dowiaduje się o pragnieniach, sympatiach, marzeniach tytułowej Marysi dopiero wtedy, kiedy kieruje na nią obiektyw amatorskiej ${ }^{5}$ kamery. Z kolei w Portrecie podwójnym (2001) Mariusza Fronta kamera cyfrowa jest notatnikiem, w którym znajdują się „szkice” Warszawy, będącej pełnoprawnym bohaterem filmu, ale również bardzo osobiste obrazy ${ }^{6}$, jak na przykład twarz śpiącej bohaterki sfilmowana przez jej chłopaka. Ponadto, rozmiary kamery cyfrowej i to, że wymaga ona niewielkiej ilości światła ${ }^{7}$ a co się z tym wiąże - użycia mniejszej liczby lamp, ułatwiło pracę z naturszczykami, których dotąd

4 Patrzę na ciebie, Marysiu zrealizowano na Becie i maleńkiej cyfrowej kamerze DV, autorem zdjęć był Kacper Lisowski, a operatorem kamery - Karina Kleszczewska.

${ }^{5}$ Piszę „amatorskiej”, bo tak kojarzono wówczas kamery cyfrowe DV, choć posługiwali się nimi również profesjonaliści, między innymi autorzy Portretu podwójnego (Jacek Januszyk, Mariusz Front i Elżbieta Piekacz), nagrodzonego podczas gdyńskiego festiwalu w 2001 roku za "poszukiwanie nowych form wyrazu”, i wspomniani już twórcy Patrzę na ciebie, Marysiu. Szczególnie ważny wydaje mi się fakt, że Edi (2002) Krzysztofa Ptaka i Piotra Trzaskalskiego, uhonorowany w 2002 roku na festiwalu sztuki operatorskiej Camerimage Złotą Żabą (i to ex aequo ze zrealizowaną na taśmie filmowej przez Conrada Halla i Sama Mendesa Road to Perdition, potem wyróżnioną również Oscarem za zdjęcia), powstał w przeważającej części na kamerze DV. W decyzji jurorów Camerimage, zrównującej film zrealizowany na negatywie z realizacją powstałą dzięki kamerze DV, widzę dowód wprowadzenia zapisu cyfrowego na operatorskie salony.

${ }^{6}$ Podobna jest w filmie dokumentalnym Marcina Koszałki Jakoś to będzie (2004), kontynuacji głośnego Takiego pięknego syna urodziłam, która kończy się obrazem twarzy córki reżysera (i operatora jednocześnie), kilkuletniej Zosi, całującej obiektyw.

7 Choć musi być ono niezmiernie precyzyjnie zaplanowane: „Negatyw jest wciąż bardziej tolerancyjny na błędy w ekspozycji, zwłaszcza na przeeksponowanie jasnych partii obrazu. Paradoksalnie, filmując na negatywie, łatwiej oświetla się plan zdjęciowy. Przy zapisie cyfrowym trzeba to robić o wiele precyzyjniej. Za to cyfra, nie mówiąc o ewidentnej oszczędności czasu i pieniędzy, oddaje, dzięki kolosalnej czułości, nieocenione usługi w trudnych warunkach oświetleniowych" A. Bukowiecki, Zawsze są tylko cienie i światła - rozmowa z Krzysztofem Ptakiem, „Kino” 2002, nr 12, s. 15. 
mogły przecież płoszyć i rozmiary filmującego aparatu, i tak zwany park oświetleniowy. Wspominam o tym dlatego, że zarówno w Edim (2002), jak i w Portrecie podwójnym oraz Złomie (2002) ${ }^{8}$, oprócz profesjonalistów, wystąpili aktorzy niezawodowi, dzięki którym realizacje zyskały niepowtarzalny autentyzm.

Tak wyglądało moje „rozpoznanie” w 2003 roku, kiedy filmowcy korzystali z kamer cyfrowych pracujących w systemie DV (małe kamerki kojarzone z działaniami amatorów) lub $\mathrm{HD}^{9}$ (dzięki takiej powstała Pornografia Jana Jakuba Kolskiego [2003] ze zdjęciami Krzysztofa Ptaka - prekursora, pioniera i mistrza między innymi używania kamer cyfrowych i cyfrowej obróbki obrazu). Dzisiaj, w 2016 roku, realizowanie filmów kamerami cyfrowymi już nikogo nie dziwi i nie jest traktowane jako artystyczna fanaberia czy jedyna szansa, by wreszcie zadebiutować, ponieważ po drodze zdążyły pojawić się dwa typy kamer cyfrowych, na których można zapisać obraz jakością dorównujący temu uzyskanemu dzięki kamerze filmowej i taśmie światłoczułej: Red Epic i Arri Alexa. Realizacja filmów „na cyfrze” stała się standardem, dlatego w niniejszym artykuletekście skupię się już nie na formie powstałych w ten sposób filmów, ale na roli kamery „obsadzonej”, czyli pojawiającej się w rękach bohaterów filmów Wojciecha Smarzowskiego. Zdecydowałam przyjrzeć się filmom akurat tego reżysera, gdyż, po pierwsze, uważam go za najciekawszego filmowca, jaki objawił się w kinie polskim po 1989 roku. Po drugie, dlatego że równie często jak siekiera, uznawana niemal za obowiązkowy rekwizyt w filmach autora Ró $\dot{z} y^{10}$, w rękach bohaterów filmów Smarzowskiego pojawia się... kamera ${ }^{11}$.

8 Złom, reż. Radosław Markiewicz, zdjęcia Dariusz Radecki. Zob. M. Lebecka, Zanim zrobię film o miłości - rozmowa $z$ Radosławem Markiewiczem, „Kino” 2002, nr 11; oraz M. Sendecka, Chciałbym strzelać - rozmowa $z$ Radosławem Markiewiczem, „Film\&TV Kamera” 2002, nr 4.

9 Zob. A. Bukowiecki, op. cit., s. 14-15.

10 Zob. Tajemnice „Drogówki”, czyli czy wiesz, że..., materiały dołączone do płyty DVD z filmem Drogówka, projekt i opracowanie graficzne E. Wastkowska, koordynacja projektu M. Kosińska, producenci wydawniczy R. Kijak i M. Skowrońska, Agora SA 2013.

${ }^{11}$ Trzy z pięciu filmów, jakie zrealizował dotychczas, powstały dzięki użyciu kamer cyfrowych: Dom zły (2009) - kamera Sony ex 1; Drogówka (2013) - przede 
Obrazy zapisane przez kamery, którymi operują bohaterowie filmów Smarzowskiego ${ }^{12}$, zawsze ujawniają prawdę. Raz chodzi o „coś” zapisanego mimochodem, przez przypadek, jak jest w debiutanckim Weselu, kiedy Kamerzysta, dochodząc do siebie w toalecie po pobiciu, dowiaduje się o cenie, za jaką Janusz poślubił Kasię. Innym razem, w Domu złym, wizja lokalna, której celem wcale nie jest dotarcie do prawdy, tylko obciążenie aresztanta zbrodniami, których nie popełnił, staje się niejako groteskowym dance macabre wykonywanym przez milicjantów. I właśnie przez ich niefrasobliwość, zbytnią pewność, że mogą przecież wszystko, kamera notabene obsługiwana przez jednego z nich - zarejestruje strzępki ujawniające prawdziwe intencje stróżów prawa. $\mathrm{Z}$ kolei w Drogówce materiały zarejestrowane przez jednego $\mathrm{z}$ funkcjonariuszy, umożliwiające mu szantażowanie sprawców wykroczeń drogowych (co wiązało się z profitami, ale doprowadziło też do jego zabójstwa), zostają wykorzystane przez innego policjanta jako dowody własnej niewinności. W Pod Mocnym Aniołem obrazy pochodzące ze szpitalnego monitoringu nadają filmowi autentyzm ${ }^{13}$, ponieważ często doprecyzowują i weryfikują wizje pacjentów cierpiących na chorobę alkoholową.

W postępowaniu bohaterów filmów Smarzowskiego nie ma nic z gestu Filipa Mosza z Amatora Kieślowskiego - w którym bohater w finale filmu kieruje obiektyw na siebie, żeby po sportretowaniu świata przyjrzeć się też

wszystkim Red Epic (do kwestii rodzajów kamer użytych podczas realizacji tego filmu wrócę w dalszej części wywodu); Pod Mocnym Aniołem (2014) - Red Epic. Tylko Wesele (2004) i Róża (2011) zostały zrealizowane kamerą filmową (i to tym samym modelem, czyli kamerą Arri bl3) na taśmie światłoczułej. W Domu złym są też fragmenty powstałe dzięki użyciu kamery Krasnogorsk, pracującej na taśmę $16 \mathrm{~mm}$. Wołyń, którego premiera ma odbyć się w październiku 2016 roku, również realizowano na „cyfrze” - użyto Alexy (za informacje o rodzajach kamer dziękuję autorowi zdjęć do Róży, Drogówki i Wołynia, Piotrowi Sobocińskiemu jr, oraz operatorowi kamery w Pod Mocnym Aniołem, Bartoszowi Piotrowskiemu).

${ }^{12}$ W Drogówce autorami nagrań, które weszły do filmu, byli aktorzy. Zob. M. Wernio, Robiąc to, co niezbędne - rozmowa z Piotrem Sobocińskim jr, „Film Pro" 2012, nr 3(11), s. 61-65.

13 Do wagi, roli i istotności autentyzmu wrócę we fragmencie poświęconym Drogówce. 
i sobie - bo nie o zdobycie samoświadomości w tym świecie chodzi. Tak zachowuje się tylko Kamerzysta z Wesela, kończąc filmowanie stwierdzeniem: „Chciałem dobrze, wyszło jak zawsze”.

Kamera w rękach bohaterów Smarzowskiego nie jest przedmiotem, jest bohaterem, wprawdzie niemym, ale potrafiącym patrzeć, a potem przekazać (obraz). Jest niezależnym świadkiem. Sprawia wrażenie medium żyjącego własnym życiem i dlatego potrafiącego ujawnić prawdę, nawet wbrew intencjom filmujących. Być może jest to interpretacyjne nadużycie, sądzę jednak, że ta reżyserska wiara w obraz - który, zdaniem Chrisa Mengesa, nie może kłamaćl $^{14}$ - jest efektem ubocznym studiów Wojciecha Smarzowskiego na wydziale operatorskim łódzkiej szkoły filmowej.

Wojciech Smarzowski, choć z wykształcenia jest operatorem filmowym, dość szybko zorientował się, że bardziej niż manipulacje światłem i kamerą interesuje go praca $\mathrm{z}$ aktorem, że więcej w nim temperamentu reżysera niż autora zdjęć. Debiutował Weselem. Ponoć było tak: najpierw zorientował się, jaki nośnik skróci mu czas czekania na debiut, a potem znalazł dla niego tak zwane społeczne uzasadnienie użycia ${ }^{15}$. Nośnikiem okazała się kamera cyfrowa. Potem trzeba było już tylko stworzyć listę wydarzeń, które nie mogą się obejść bez kamery cyfrowej. Ślub i wesele okazały się najbardziej nośnymi znaczeniowo, a jednocześnie umożliwiły nawiązanie do twórczości Wyspiańskiego ${ }^{16}$, który, jak przyszłość pokaże, stanie się artystą ważnym dla Smarzowskiego - reżysera tak bardzo zainteresowanego reinterpretacją, a może nawet dekonstrukcją ważnych dla nas mitów. Kiedy zwróciłam się

${ }^{14}$ Chris Menges - wywodzący się z tradycji dokumentarystycznej wybitny autor zdjęć między innymi do Kesa Kena Loacha czy Pól śmierci i Misji Rollande’a Joffe’a. Zob. K. Taras, Zdjęcia nie moga kłamać - rozmowa $z$ Chrisem Mengesem, „Film PRO” 2015, nr 4(24), s. 5-8.

15 Zob. K. Taras, Blaski i cienie kamery cyfrowej, [w:] Historia kina polskiego, red. T. Lubelski, K.J. Zarębski, Warszawa 2007, s. 258-260.

${ }^{16} \mathrm{~W}$ debiucie reżyserskim Smarzowskiego pojawia się stwierdzenie „Trza być w butach na weselu", które wypowiada okradziony i pobity Wojnar, jednak o wiele ważniejsze wydają mi się nawiązania do prac plastycznych Wyspiańskiego - inserty, czyli krótkie ujęcia będące filmowymi wersjami Śpiącego Stasia i Macierzyństwa, dające widzowi moment spokoju. Zob. K. Taras, „Egoista” czy Edi? Bohaterowie najnowszych polskich filmów - rekonesans, Warszawa 2007, s. 138-139. 
z prośbą o potwierdzenie legendy „cyfrowego” powstania Wesela do Piotra Sobocińskiego jr, autora zdjęć, z którym, jak na razie (i sądząc po efektach - oby jak najdłużej) Smarzowski najczęściej pracował przy realizacji pełnometrażowych filmów fabularnych, okazało się, że jest to tylko legend a, ponieważ film powstał na... taśmie $35 \mathrm{~mm}$, czyli przy użyciu kamery filmowej. Powodów powstania tej „cyfrowej legendy” nie potrafię podać.

Akcja Wesela dzieje się na jednej z podkarpackich wsi i obejmuje czas ślubu oraz wesela Kasi (Tamara Arciuch) i Janusza (Bartek Topa), czyli od popołudnia do świtu następnego dnia. Dla porządku wywodu wyjaśnię, że $\mathrm{w}$ filmie mamy do czynienia $\mathrm{z}$ dwiema kamerami: jedną, którą film zrealizowano, i drugą, którą operuje jedna z ekranowych postaci - Kamerzysta (Maciej Stuhr), wynajęty przez Wojnara (Marian Dziędziel), żeby utrwalić wesele córki, ale przede wszystkim żeby ludzie widzieli, że najbogatszego gospodarza stać na taką usługę. Fakt, że Kamerzysta używa niewielkiej kamery DV, wywołuje oburzenie Wojnarowej (Iwona Bielska) - „Chyba już mniejszej kamery nie mieli!” - bo przecież tak małej ludzie mogą nie zauważyć. Ujęcia „zrealizowane” przez Kamerzystę pojawiają się w filmie już na samym początku - są insertami przerywającymi rozpoczynającą realizację sekwencję ślubu, dzięki czemu, po pierwsze, informują widza, że będzie miał do czynienia $\mathrm{z}$ filmem $\mathrm{w}$ filmie (to znaczy otrzyma zdjęcia zrealizowane przez ekipę autora zdjęć, Andrzeja Szulkowskiego, i te, których „autorem” jest jedna z postaci - Kamerzysta), a jednocześnie, po drugie, poprzez swój dynamizm - niepokoją go. Zdjęcia wykonane przez bohatera są, oczywiście, bardziej chaotyczne, chropowate, na granicy „wizualnego brudu". Jednak im dłużej oglądamy Wesele, tym bardziej przekonujemy się, że film i „film w filmie” jakoś szczególnie mocno wizualnie od siebie nie odstają, że materiały nagrane przez Kamerzystę ${ }^{17}$ idealnie dopełniają nagranie „oficjalne”. I może to właśnie ta „przaśność” spowodowała „cyfrową” legendę powstania Wesela? Obraz zrealizowany najszlachetniejszym i cieszącym się największym szacunkiem pośród autorów zdjęć narzędziem, czyli kamerą filmową, na najszlachetniejszym materiale, czyli taśmie $35 \mathrm{~mm}$, naprawdę przypomina amatorskie filmy video (!) kręcone na weselach. Warto w tym momencie zauważyć, że autor zdjęć, Andrzej Szulkowski, wykroczył w ten

17 Fragmenty zarejestrowane przez Kamerzystę zrealizowano kamerą cyfrową DV. 
sposób poza reguły sztuki operatorskiej, co wymaga i wielkiej świadomości warsztatu autora zdjęć (wyczucia tego, które zasady można zlekceważyć, a które trzeba respektować), i pokory.

Kamerzysta zarejestrował „drugie życie” wesela, podskórną egzystencję obecną poza narracją składanych życzeń. Widzimy chaotyczne obrazki i słyszymy jednocześnie nagrane wypowiedzi o nieświeżym jedzeniu, „chrzczonej” wódce, motywach Janusza, który zbyt szybko poślubił Kasię, bo „pewnie dziecko jej zrobił”, skąpstwie i jednocześnie bogactwie Wojnara. Obserwujemy zabawy weselne, wywołujące zażenowanie u panny młodej. Kilka razy możemy dostrzec jej twarz, która absolutnie nie przypomina twarzy kobiety zadowolonej z zamążpójścia, bawiącej się dobrze na własnym weselu. Kasia uśmiecha się wtedy, kiedy panna młoda raczej nie powinna, na przykład gdy niezgrabny świadek upuszcza obrączki. Raz dziewczyna przejmuje kamerę i filmuje, jak namówieni przez nią miejscowi siepacze biją Kamerzystę. Okazuje się, że to on jest ojcem jej dziecka, że ją zdradził i zostawił. I dlatego Wojnar postawił córkę przed alternatywą: albo aborcja, albo ślub z zakochanym w niej kiedyś, ale przez dziewczynę niedostrzeganym, Januszem, który zgodził się na wszystko nie z miłości, tylko dla samochodu Audi TT. Kamerzysta chciał zobaczyć, czy Kasia jest szczęśliwa, i dlatego poprosił o przysługę właściciela firmy filmującej wesela. I to właśnie tłumaczy chaotyczne obrazy z początku filmu - bohater uczył się obsługi kamery DV. Materiały nagrane przez Kamerzystę okazują się księgą przysłów, prawd życiowych i wyznań społeczności, w której króluje (ze względu na swój stan posiadania) Wojnar. Wyznań częstokroć przejmujących, jak w przypadku matki pokazującej zdjęcia syna, „dobrego chłopaka”, który tylko za często pije i wtedy bije... Reszty wypowiedzi możemy się domyślić. Kamerzyście udało się zapisać wydarzenia, które ujawniają prawdę o motywach postępowania bohaterów. Niewprawnie zrealizowane nagrania demaskują hipokryzję gości, którzy przyszli na wesele, ale wcale młodym dobrze nie życzą, a zjawili się, żeby zobaczyć, co się nie uda, i z lęku przed obrażeniem Wojnara. To z filmiku zarejestrowanego niemal przez przypadek w toalecie, gdzie doprowadzał się do porządku pobity Kamerzysta, Kasia dowiaduje się o transakcji, której stała się przedmiotem, i o śmierci dziadka, który nie zniósł prawdy o tym, jak jego zięć potraktował wnuczkę - Wojnar, żeby zaoszczędzić, sprowadził samochód dla Janusza zza zachodniej granicy, częścią zapłaty miała być też ziemia dziadka, przez którą planowano 
poprowadzić autostradę, o czym bohater nie wiedział; teść nie godził się na zapis, nie chciał ulec zięciowi, w końcu, załamany sytuacją wnuczki, dostał ataku serca. Kamera w rękach bohatera Wesela rejestruje przewinienia społeczności, jest świadkiem starań Wojnara ${ }^{18}$, żeby wszystko było „jak należy”, to znaczy zgodnie z regułami respektowanymi przez zbiorowość, w jakiej żyje. Ale jest też intymnym notatnikiem mężczyzny nadal kochającego Kasię, o czym świadczą długo wytrzymywane zbliżenia jej twarzy, co przypomina trochę sytuację z Portretu podwójnego (oraz Jakoś to będzie) i jednocześnie potwierdza, że kamera cyfrowa, również ta zamontowana w telefonie komórkowym, funkcjonuje dziś jako miejsce przechowywania najbardziej intymnych i ważnych dla nas wspomnień, pełni rolę niemal talizmanu (przekonująco pokaże to Piotr Szczepański w Alei Gówniarzy [2006], w sekwencji popisywania się przed bezdzietnym Marcinem [Marcin Brzozowski] wybrykami pociech zarejestrowanymi komórkami rodziców). Szczególnie ważny wydaje mi się fakt, że również jedno z bezpośrednich nawiązań do twórczości Wyspiańskiego, którego wpływu na przaśny przecież estetycznie film Smarzowskiego nie można nie docenić i nie dostrzec, czyli ujęcie zainspirowane pastelem Macierzyństwo (ciemnowłosa kobieta karmi piersią dziecko, czemu przyglądają się dziewczynki z wielkimi kokardami we włosach), „pochodzi” od Kamerzysty, co tylko potwierdza dystans bohatera, jego umiejętność obserwowania i skupiania się na tym, co innym umyka. Tylko Kamerzysta dostrzega karmiącą matkę, reszta gości jest już tak pijana, że nie kontroluje ani swoich odruchów, ani tego, co dzieje się obok. Warto chyba teraz zapytać, skąd obecność tej kobiety w towarzystwie, od którego wyraźnie odstaje i urodą, i ubiorem? Do historii nie wnosi ona przecież nic nowego, choć, owszem, przez jej postać reżyser ewidentnie odsyła nas do Wyspiańskiego, zapowiada „chocholi taniec”, który w tej przestrzeni będzie polegał na odśpiewaniu Roty przez nieprzytomnych od alkoholu gości ${ }^{19}$. Być może ciemnowłosa kobieta i towarzyszące jej dzieci są zjawami,

18 Mimo całego łotrostwa mężczyzny, nie potrafię uznać go za jednoznacznie negatywnego bohatera, ponieważ Wojnar jest po prostu produktem zbiorowości, jaką współtworzy. Osobami, które sprzeciwiają się hipokryzji i kultowi pieniądza, są tu tylko dziadek i Kasia.

19 To pierwsza $\mathrm{z}$ arcymocnych i arcyznaczących scen w filmach Smarzowskiego, które również można uznać za jego autorski podpis. Te sekwencje wybijają widzów 
co również mogłoby stanowić nawiązanie do Wesela Wyspiańskiego, gdzie od zjaw, ukazujących się tylko niektórym bohaterom, aż się roi? Być może kobietę i dzieci widzi tylko Kamerzysta, a może „widzi” je tylko i rejestruje ich obecność ta kamera, która żyje w filmach Smarzowskiego wła s ny m życie m, zapisując chwilami raczej to, co sama chce, niż to, co i tak umknęłoby uwadze kogoś, w kogo ręku spoczywa.

Podobnie będzie przecież w Domu złym, gdzie kamera, mająca posłużyć za narzędzie dokumentujące wizję lokalną, zarejestruje a to pijanego prokuratora (Robert Więckiewicz) wpadającego do rowu, a to inscenizację zabawy, która poprzedziła mord, a to dogadywanie się milicjantów i prokuratora, jak unieszkodliwić porucznika Mroza. Takich rzeczy nie mógł przecież sfilmować funkcjonariusz obsługujący aparat. Można zatem chyba powiedzieć, że w filmach Smarzowskiego mamy do czynienia z ,inteligentną kamerą”, choć może bardziej pasuje tu określenie: „sprawiedliwą kamerą”, skoro aparat filmujący „chwyta” chwile prawdy, ujawnia prawdziwe intencje i motywacje bohaterów.

W Domu złym „występuje” kamera Krasnogorsk, pracująca na taśmie 16 mm, która jest tu czymś więcej niż zwykłym rekwizytem, ponieważ to przy jej użyciu zrealizowano sekwencję wizji lokalnej przeprowadzonej w lutym 1982 roku w tym, co pozostało po pożarze z gospodarstwa Dziabasów (Kinga Preis i Marian Dziędziel), stanowiącą znaczną i znaczącą część filmu (reszta powstała dzięki skorzystaniu z cyfrowej kamery Sony ex 1).

Na przykładzie Domu złego doskonale widać, że w świecie Smarzowskiego nie jest ważne, kto trzyma kamerę. Na podstawie Wesela można by wysnuć wniosek, że kamera znajduje się w rękach kogoś, kto chce rozpoznać sytuację,

z - jak to określiła Maria Janion - „zakochania we własnej piękności” (M. Janion, „Czy będziesz wiedział, co przeżyłeś”, Warszawa 1996, s. 15). W Domu złym takimi scenami będą: wyrzucenie porucznika Mroza $\mathrm{z}$ wiejskiego sklepu przez skandujących „Solidarność, Solidarność!” i układających palce w znak Wiktorii złaknionych wódki i papierosów kolejkowiczów, a także ustawienie się milicjantki w zaawansowanej ciąży po przypadającą na każdego uczestnika wizji lokalnej „kolejkę" wódki; w Róży - przedostatnia sekwencja pokazująca, że gospodarstwo Róży Kwiatkowskiej przejęli przesiedleńcy zza Buga, których kobieta serdecznie ugościła. Drogówka, film najbardziej intensywny, niemal rozjątrzony wizualnie, składa się niemal z samych takich scen. 
kogoś, komu zależy na poznaniu prawdy (Kamerzysta chce poznać powody zamążpójścia Kasi, a także sprawdzić, czy dziewczyna będzie mieć szansę na szczęście), wreszcie kogoś, kto nie będąc członkiem społeczności, a zatem zachowując dystans wobec wydarzeń i postaci ( $\mathrm{z}$ wyjątkiem stosunku do Kasi), będzie mógł wszystko osądzić. W Domu złym na początku dajemy się zwieść, że Jasiak (Grzegorz Wojdon), milicjant, który ma rejestrować wizję lokalną, jest postacią pozytywną. Okazuje się jednak, że tak nie jest, bo to on informacją „Wrabiają cię, spierdalaj stąd!” prowokuje aresztanta Środonia (Arkadiusz Jakubik) do ucieczki, a potem filmuje mężczyznę, który zatrzymał się, wstrząśnięty widokiem ciała zamordowanego porucznika Mroza (Bartłomiej Topa), i podniósł nóż, którym zabito porucznika.

W świecie Smarzowskiego kamera (przypomnijmy, że chodzi o tę obecną na ekranie) jest o wiele ważniejsza niż ten, kto nią operuje. Jest świadkiem, jak gdyby była bardziej świadoma niż jej operator i lepiej wiedziała, co należy nagrać. Jest niezależna. Potwierdza to Dom zły. Celem wizji lokalnej przecież wcale nie jest ani ustalenie prawdy, ani choćby rekonstrukcja sytuacji, która doprowadziła do podwójnego zabójstwa i samobójstwa w obejściu Dziabasów, tylko obciążenie Środonia zamordowaniem Dziabasa, jego żony i syna, a potem dodatkowo jeszcze zabiciem Mroza, który pracując nad sprawą pechowego zootechnika, przez przypadek zbliżył się do zagadkowych malwersacji w pegeerze, co na tyle zaniepokoiło władze, że pofatygował się do niego wysoki rangą ubek w drodze do Arłamowa i w zamian za przerwanie prywatnego dochodzenia zaproponował awans. (W ciągu kilku godzin Mróz ustalił więcej niż inni przez kilka miesięcy, dlatego że, po prostu, chciał poznać prawdę o nieuczciwościach i pechowym zakręcie, na którym ginęli niewygodni świadkowie kradzieży.) Dla jasności wywodu wyjaśnię, że zootechnik Środoń zjawił się w zagrodzie Dziabasów jesienią 1981 roku, ponieważ po śmierci żony chciał zacząć nowe życie w jakimś odległym miejscu. Dostał propozycję pracy w pegeerze w Bieszczadach, a $z$ racji tego, że autobus, którym podróżował, miał awarię, mężczyzna, by nie marnować czasu, dalszą część drogi postanowił pokonać pieszo. Wybrał skrót przez pole Dziabasów, pogryzł go ich pies, a jako rekompensatę gospodarze zaproponowali mu poczęstunek, mocno podlany alkoholem. Bimber dodał bohaterom animuszu i tak ich zbliżył, że Dziabas i Środoń zaczęli planować wspólne przedsięwzięcie - produkcję alkoholu na niemal przemysłową skalę. Środoń pokazał Dziabasom oszczędności pochodzące 
między innymi z ubezpieczenia żony, a ci postanowili go zabić. Gościowi posłano w pokoju Janusza, syna Dziabasa. Zootechnik na chwilę wyszedł, po czym w pokoju położył się jego „prawowity” lokator, który następnie zginął z ręki własnego ojca, przekonanego, że morduje gościa ${ }^{20}$. Dziabas, załamany faktem, że uśmiercił syna - zabił też i żonę, a potem się powiesił. O zbrodnie oskarżono Środonia. W Domu złym ujęciami, które przyciągają największą uwagę i najbardziej przejmują widza, są zbliżenia ukazujące Środonia przerażonego faktem, że obciąża się go odpowiedzialnością za czyny, których nie popełnił. O tym, że mord jest dla niego czymś abstrakcyjnym, że nie mieści się w kanonie jego wartości, świadczy protest, by nie filmować go z siekierą, którą na siłę wciskają mu milicjanci. Jeden z wielu paradoksów czy dwuznaczności tego filmu, które świadczą tylko o jego wartości, polega na tym, że kamera, narzędzie, które miało posłużyć spreparowaniu kłamstwa, obciążeniu niewinnego człowieka, wychwytuje elementy prawdy, i to wyraźnie wbrew przewijającemu się przez cały film stwierdzeniu: „Prawda? Nie ma takiej”.

Zastanawiam się, czy tej inteligentnej, wolnej, sprawiedliwej kamery, "grającej” w filmach Smarzowskiego, nie można powiązać z charakterystycznym dla tworzonego przez niego kina ostatnim ujęciem, w którym z góry oglądamy miejsce akcji, ogarniamy wzrokiem przestrzeń, gdzie działy się zaprezentowane nam wydarzenia, i bohaterów, których dramaty zdążyliśmy poznać? Czy nie można skojarzyć jej ze spojrzeniem tego Kogoś, kto, mimo wszystko, panuje nad tym światem, ale nie ingeruje weń? Kogoś, za czyją obecnością autor tęskni. Może ten Ktoś operuje również kamerą i dlatego ta staje się sprawiedliwa, widząca i wiedząca?

W Drogówce urządzenia zapisujące obraz na pewno obsługują ludzie. Bohaterowie za pomocą iPhone'ów, traktowanych jak dzienniki intymne, utrwalają chwile radości, takie jak firmowa impreza, kawały robione Hawrylukowi, piłkarskie sukcesy syna Króla. Z kolei funkcjonariusz policji drogowej, Lisowski (Marcin Dorociński), rejestruje komórkami wykroczenia ludzi, których potem będzie szantażować. Podobnie zachowuje się Hawryluk (Robert Wabich) filmujący sierżanta Króla (Bartek Topa) w drodze do agencji

20 Wszelkie skojarzenia z Niespodzianką Rostworowskiego są jak najbardziej na miejscu, właśnie tym dramatem inspirowali się bowiem autorzy scenariusza Wojciech Smarzowski i Łukasz Kośmicki. 
towarzyskiej, a potem już w samym przybytku, by potem obciążyć go zabójstwem Lisowskiego. Jednym z odczytań Drogówki może być uznanie jej za film o potędze obrazów ${ }^{21}$, ale jeszcze bardziej o tym, że wszystko zależy od tego, w czyich rękach znajdzie się nagranie i jaki nada mu się kontekst. Filmy, które umożliwiły Lisowskiemu szantaż, Król wykorzystał jako podstawę dla swojego alibi. Upowszechnił też nagrania z orgii, w której brali udział politycy i biznesmeni, choć za przerwanie prywatnego śledztwa (kolejnego w świecie wykreowanym przez Smarzowskiego) obiecywano mu łapówkę. Bohater nie uległ szantażowi, sam też nikogo nie chciał szantażować (jak mord nie mieścił się w mentalności Środonia, a zrezygnowanie z dotarcia do prawdy w naturze porucznika Mroza, tak Król nie akceptował szantażu), i dlatego powiadomił społeczeństwo o tym, jak zachowują się jego

${ }^{21}$ O tym, że Drogówka może być interpretowana jako film o potędze obrazu, może świadczyć fakt, ilu rodzajów kamer używała ekipa podczas realizacji filmu, a wszystko po to, aby obrazowi nadać autentyzm. Jak wyjaśnia autor zdjęć, Piotr Sobociński jr: „Naszym podstawowym założeniem była chęć zbliżenia się do realizmu, ale niekoniecznie przez naturalizm. Inaczej postrzegamy świat, kiedy jesteśmy pod wpływem silnych emocji. Chcieliśmy to przenieść na ekran. Zrezygnowaliśmy z naturalistycznego, obiektywnego spojrzenia na rzecz na scen przefiltrowanych przez towarzyszące im emocje. [...] Używaliśmy wielu nośników, bo to jest po prostu zapisane w scenariuszu i zbliża nas do prawdy. Główną kamera jest Red Epic. Nie chcieliśmy wszystkiego filmować na Epiku, a potem degradować wybranych scen. Zależało nam na zachowaniu głębi ostrości i wszystkich charakterystycznych cech dla poszczególnych formatów. Używaliśmy iPhone’ów, kamer przemysłowych, kamer GoPro, długopisów z ukrytą kamerą, materiałów policyjnych rejestrowanych na analogowej kamerze Hi8, a także wideorejestratorach. Wszystkie te urządzenia filmowały, a także występowały w filmie jako rekwizyty. Mieliśmy sceny dziejące się w autobusie, podczas których używaliśmy dwóch Epików, a połowa aktorów miała telefony i filmowała się nawzajem. Do jednej sceny wykorzystaliśmy piętnaście nośników! Współczuję montażyście, który potem musiał to wszystko przejrzeć. Ciekawostką jest, że iPhone okazał się zbyt dobry i nakręcony nim obraz trzeba było degradować. Różnica nie jest tak duża, jak oczekiwaliśmy. Musimy znaleźć dla tego obrazu odpowiednią fakturę, ponieważ zależy nam na tym, aby zachować autentyzm i wielość formatów. [...] Koncepcja jest taka, że granica między światem obiektywnym, a więc Epikiem, a subiektywnym, czyli pozostałymi nośnikami, w pewnym momencie się zaciera” M. Wernio, op. cit., s. 62-63. 
reprezentanci. W efekcie, podobnie jak Mróz, został zamordowany (notabene obie role zagrał ten sam aktor).

Jednak w świecie wykreowanym przez Smarzowskiego dokonał się jakiś postęp, ponieważ tym razem winni zostali ukarani, a przynajmniej w ostatnim ujęciu (oczywiście zrealizowanym w przeważającej części w planie ogólnym kamerą skierowaną w dół) pojawiła się na to nadzieja - przełożony Króla został aresztowany na pogrzebie swojego podkomendnego przez funkcjonariuszy wydziału wewnętrznego. Może ów progres wziął się z faktu, że tym razem Smarzowski opisuje Polskę po przełomie 1989 roku, a akcja Domu złego rozgrywała się tuż przed wprowadzeniem stanu wojennego i podczas jego trwania? Jeśli tak, to mimo tego, że wizerunek Polski, z jakim mamy do czynienia w Drogówce, może przerażać i odstręczać (widzimy społeczeństwo przeżarte korupcją, normy przekracza się i w przestrzeni prywatnej, i publicznej), to wyraźnie widać, że teraz jest szansa na sprawiedliwość i ukaranie winnych, o czym w świecie (i czasach) Domu złego nie było mowy.

\section{Bibliografia}

Andrzej Bukowiecki, Zawsze sq tylko cienie i światła - rozmowa $z$ Krzysztofem Ptakiem, „Kino” 2002, nr 12.

Maria Janion, „Czy będzie wiedział, co przeżyłeś”, Sic!, Warszawa 1996.

Magda Lebecka, Zanim zrobięfilm o miłości - rozmowa z Radosławem Markiewiczem, „Kino” 2002, nr 11.

Magda Sendecka, Chciałbym strzelać - rozmowa $z$ Radosławem Markiewiczem, „Film\&TV Kamera” 2002, nr 24.

Katarzyna Taras, Blaski i cienie kamery cyfrowej, [w:] Historia kina polskiego, red.

T. Lubelski i K.J. Zarębski, Fundacja Kino, Warszawa 2007.

Katarzyna Taras, „Egoista” czy Edi? Bohaterowie najnowszych polskich filmów rekonesans, Wydawnictwo UKSW, Warszawa 2007.

Katarzyna Taras, Komu cyfra sprzyja, „Kwartalnik Filmowy” 2003, nr 43.

Katarzyna Taras, Zdjęcia nie moga kłamać - rozmowa z Chrisem Mengesem, „Film Pro" 2005, nr 4(24).

Maciej Wernio, Robiąc to, co niezbędne - rozmowa z Piotrem Sobocińskim jr, „Film Pro" 2012, nr 3(11). 


\section{The Role of the Camera in the Films by Wojciech Smarzowski}

In this paper, I reflect on the role and function of the camera 'acting' (that is, the camera placed in the hands of the heroes of films by Wojciech Smarzowski) that appears on the screen as often as an ax - item strongly associated with this director's cinema.

I also refute the 'digital' legend of his debut, i.e. Wesele (Wedding), which has not been realized with the use of a digital camera, but a film one.

A camera 'casted' in the films by Smarzowski can be considered as an extra, but a full-fledged hero, a witness seeing (and therefore recording) more than the character whose hands it is located in. This perfectly corresponds with the last shot - perhaps the most characteristic one for the author of the films discussed - the shot in which the One who reigns over the world, but does not interfere into it (since we have free will) gazes at the universe created by Wojciech Smarzowski.

Keywords: Wojciech Smarzowski, digital camera, operator's art, final shot, Poland after ' 89 , film image, light in movie 